\title{
Digital Sector Innovation to Support Less Contact Economy in Indonesia
}

\author{
Yuda Syahidin \\ Information Technology faculty, Information System Department, Piksi Ganesha Polytechnic, Gatot Subroto Street No \\ 301, Bandung \\ *Corresponding author. Email: yudasy@gmail.com
}

\begin{abstract}
The paper presents the digital economy strengthening that acted as a stabilizer in the economic sector during the Covid19 outbreak. In the lockdown period, most interactions between customers and suppliers must occur virtually. Although it still makes exceptions, digital operating is the only way to survive government restrictions on activities, including in the economic sector. This study uses the literature review method by taking from further research and expertise, and relevant information from the internet can recommend facing the pandemic period in business digitally by supporting Less Contact Economics. Digital companies use technology to create new value in business models, customer experiences and the internal capabilities that support their core operations. The term includes both digital-only brands and traditional players that are transforming their businesses with digital technologies. When face-to-face activities are difficult to do today, digital technology is the only solution that can 'force' business people to try this technology. This research will produce digital sector innovations that create several technology platforms in this new normal, namely Logistics and Supply Chain, EdTech, FinTech, AgriTech, HealthTech, SecurityTech. So, hoping that the digital sector is encouraged to reduce the worst impact on the economy. For example, being a substitute for economic activity that is currently limited and also the retail industry, the service sector that is directly affected amid the Covid-19 outbreak in the future is less contact economy. Innovation in the digital industry is increasingly needed to fill the diminishing faceto-face activities.
\end{abstract}

Keywords: Innovation, Digital Sector, Less Contact Economy.

\section{INTRODUCTION}

The COVID-19 pandemic is far more than a health crisis: it affects society and the economy at its core. While the impact of a pandemic will vary from country to country, it is likely to increase poverty and inequality on a global scale, making achieving the Sustainable Development Goals (SDGs) even more pressing [1].

Indonesia is included in the list of 170 countries that will experience a decline in economic growth due to Covid-19, so digital transactions and services must be a mainstay. But can the digital sector reduce the worst impact of the economy, for example, as a substitute for economic activities currently restricted? Currently, the world is being hit by COVID-19 pandemic [2]. It is undeniable that this pandemic has had an impact on aspects of human life. One of them is the economy which weakened in a short time. As reported by London Time regarding the development of the COVID-19 case, which occurred within 30 days, you can see Figure 1 [3].

Economic factors that occur in recession will bring the country to new problems (education, environment, culture, and legal certainty). For example, those who work in the trade sector play a significant role in the country's economic progress. If production, distribution and consumption patterns are hampered, the key to a country's success in meeting its population's needs will disrupt. Micro, Small and Medium Enterprises (MSMEs) have had a significant impact so far because they do not have much capital, so they experience a decline in turnover spikes [4].

It raised Less Contact Economy because during the pandemic and afterwards, face-to-face businesses will decrease. With this, digital sector innovation is increasingly developing after the COVID-19 pandemic. In the "new normal" era, activities must be carried out but still must maintain physical distance [5]. Not only that, 


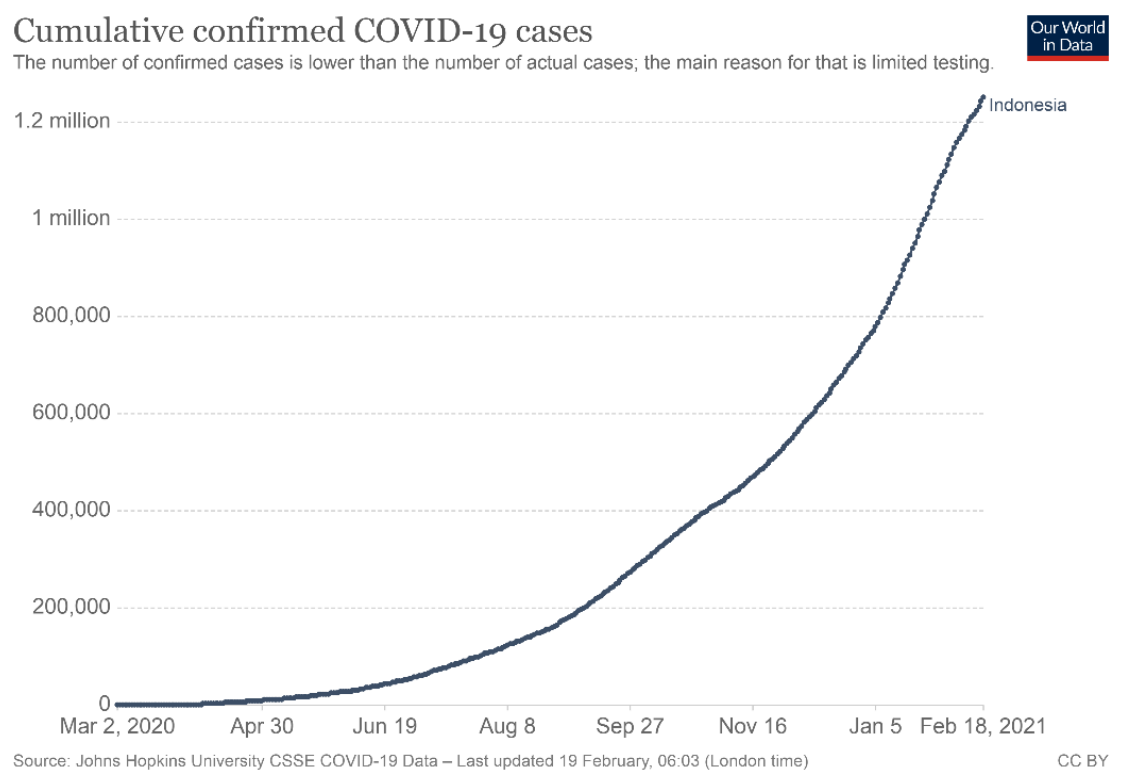

Figure 1 Daily new confirmed the COVID-19 cases [3].

to help prevent and deal with the COVID-19, assistance from technology is now needed. It triggers technology experts to research further for innovation. Increasing the use of digital technology is one of the steps to accelerate the economy. During a pandemic, digital technology helps keep the economy rolling when offline activities stop. It is the most incredible opportunity for the digital sector to substitute for the reduction in in-person meetings, meetings or other activities so that It can apply a digital economy application. Therefore, digital innovation is needed in the economic field and the medical or medical fields.

The purpose of this paper is to provide proposals in digital innovation in response to the challenges presented by the COVID-19 from governments and regulators around the world, supported by the private sector and the digital development community. And perhaps turn this challenge into an opportunity to build a stronger society that can withstand social emergencies, economic and political.

\section{LITERATURE REVIEW}

\subsection{Digital Business}

Digital businesses use technology to create new value in business models, customer experiences and the internal capabilities that support their core operations. The term includes digital-only brands and traditional players, transforming their businesses with digital technologies [6].

Digital business is one of the critical and valuable industries' names today, and it is the combination of business and IT components and its uses [6].
The internet has transformed the music, tourism, trade and service industries and is considered essential in all economic activity. Digital business plays a significant role in creating relationships with individuals, businesses, transactions, educational organizations. Educational institutions are among the leading players in creating a new workforce capable of creating new business models, strategies and technologies combined with digital business. The continuous wrong digital business encourages the convergence of technology, people, and business into e-business to e-commerce. A digital company is also referred to as the combination and interconnection between the stakeholders and industry. Another term said as the information, technology and business combination. Digital business is very close to the fields and aspects of Electronic Business, Electronic Commerce and Digital Marketing [7]. Digitalization also changes the retail ecosystem that exists in conventional shops or places of business.

\subsection{Innovation}

Innovation is a social and economic success due to the new ways or new combinations' introduction and old ways of converting inputs into outputs in such a way as to produce significant changes in the ratio between the value of benefits and prices according to the perception of consumers and/or users. The definition of innovation is an idea, idea, practice, or object realized and accepted as something new by a person or group for adoption [8]. Meanwhile, product innovation is a combination of various processes that influence one another. It can also understand that design is not a concept, new idea, or new invention or the development of a new market, but is a description of all the existing processes. Innovation has four primary characteristics: uniqueness or uniqueness, 
which can represent ideas, systems or stages, has a novelty nature, is implemented through a planned program, and must have the desired end goal.

\subsection{Digital Transformation in Pandemic and Post-Pandemic Era [9]}

The concepts of "digital technology" and "digital economy" can be explained based on scientific dictionaries due to changes in 21st-century technology regarding the "combination" of telecommunications, information and communication technology and innovation. Information and communication technology (ICT) enables globalization to promote local products globally, namely equal participation in the global network economy [10]. The advantages of using digital technology are better delivery in government services through complete and integrated public administration activities, increased interaction with the business and industry sectors, quality and fast response to needs, citizen participation in building an information society, effective government management, increasing the number of ICT experts and increasing literacy to ICT.

\section{METHOD}

Based on this background, the writer explores using information technology as an innovative solution in maintaining business sustainability. Research is carried out through theoretical and conceptual deepening through data collection and information relating to Digital Business and innovation management by supporting data sourced from national and international research journals and keeping books, newspapers, magazines, and other supporting scientific articles. Conceptual studies in the form of literature studies have several objectives: to inform readers of the results of other examinations or previous studies that are closely related to the research carried out at that time, by connecting the research with existing literature, and to fill in the gaps in the previous analysis. This study will contain reviews, summaries, and writers' thoughts on several literature sources (articles, books, slides, information from the internet, etc.) on the topics discussed.

\section{RESULT AND DISCUSSION}

Like previous research that discusses global economics's influence due to the COVID-19 [4] in transactions can be reduced by continuing to trade but adhering to Less Contact economics. The COVID-19 pandemic has transformed into a shift in sales patterns and Indonesian consumers' purchasing behavior from conventional transaction patterns to digital transaction patterns. It indirectly leads to increasingly unstoppable internet usage and a change in Indonesians' conduct who use mobile applications to make transactions.
The Less Contact Economic is a combination of people who want economic activity to run and apply strict health protocols, and the economy remains productive, and the community remains healthy. The less contact economy solution is characterized by hyperconnectivity between people, but no longer physically or face to face but through information and communication technology.

It can see from the use of e-commerce that has been carried out in the community so far, where now many people are familiar with online shopping. Likewise, logistics activities [11] have also adjusted to the less contact economy.

Based on observations and information regarding physical distancing restrictions in the New Normal era, it resulted in producing a new platform in digital sector innovation to support less contact economy, including the following:

\subsection{Logistic and Supply Chain}

The goods delivery or logistics service business must innovate because the Covid-19 pandemic has not yet subsided in the country. Generally, this business sector experienced an increase during the Covid-19 Pandemic. The \#Stay at Home movement was driven by the stay-athome movement during the PSBB (Large-Scale Social Restrictions). Stay at home requires e-commerce and logistics service solutions to fulfil orders and deliver orders to homes.

Covid-19 also teaches supply chain innovation. When the demand for online groceries increases sharply, while consumers are self-isolating, many online retailers experience supply chain constraints. Generally, they have problems when delivering goods through distribution center warehouses for quite a long distance. Many retailers are innovating the supply chain by developing hub channels for goods delivery. They use their outlets to send products to consumers.

\subsection{EdTech}

The use of information and communication technology to provide educational services has promising potential to improve learning outcomes. More than 530,000 schools have been closed in Indonesia to reduce the spread of the coronavirus (COVID-19) [12]. It impacts 68 million students from pre-school to tertiary level and makes the need for effective EdTech even more urgent. The situation forced a rapid and widespread increase in the use of EdTech in the country and expected to have a lasting effect on the market.

The EdTech landscape survey in Indonesia that we recently published reveals that the EdTech sector in Indonesia is catching up with achievements at the global level. The survey noted the growth of local platforms such as Harukaedu (a platform that offers degrees in 
higher education online), Ruangguru (an interactive elearning platform for students from kindergarten to grade 12 in Indonesia) and Cakap by Squline (a tutoring platform for language learning). However, in general, this sector is still only beginning to develop. The following is a picture of trends in the use of EdTech [2] you can see in Figure 2.

The reluctance among some educational institutions, teachers and parents to adopt technology has changed due to the pandemic, as almost everyone now relies on online and distance education methods. It is predicted that the pandemic will accelerate the adoption of online learning methods and encourage educational institutions to use distance learning to strengthen resilience to future crises.

\subsection{FinTech}

The financial technology or Fintech industry is considered to have the potential to help economic recovery during the coronavirus pandemic. A conducive regulatory environment is one of the industry's assets to support the people's economy aggressively.

The Fintech industry has great potential to boost Indonesia's economic growth, especially under challenging conditions. It is not only due to the industry's state, which is still thriving, but also can touch a broader segment of society.

Fintech also plays an essential role in distributing social assistance from the government to promote economic recovery after the Covid-19 pandemic. An example of the presence of a Pre-Employment Card in collaboration with a fintech payment provider of emoney to distribute assistance to unemployed people in the form of online training.
Besides, Fintech payments have also been active in the Proud Indonesia campaign by providing seamless, safe solutions and impacting MSMEs. It is in line with the government's plan to launch a federal stimulus to encourage UMKM products.

\subsection{AgriTech}

The government has imposed large-scale social restrictions or PSBB in various areas to prevent the transmission of Covid-19. Although aimed at limiting people's traffic, this policy also impacted the flow of goods, including foodstuffs.

AgriTech uses technology in agriculture, horticulture and aquaculture to increase yields, efficiency and profitability. AgriTech can be a product, service or application derived from agriculture that enhances various input and output processes. With technology, the distribution chain can be cut so that logistics can be more efficient. Technology also allows farmers upstream to reach consumers directly. That way, it can avoid the price game by intermediaries can be avoided.

\subsection{Health Tech}

One of the digital sector innovations that may be in direct contact with this pandemic is HealthTech. Community needs for health services can still be served even though they have limited direct interaction through digital health service platforms.

It can also see this increasing need for information from the declining hospital visit data but an increase in the use of teleconsultation services by the community during this pandemic. The public, doctors, and hospitals are now also starting to look for digital platforms to serve patients despite various limitations still.

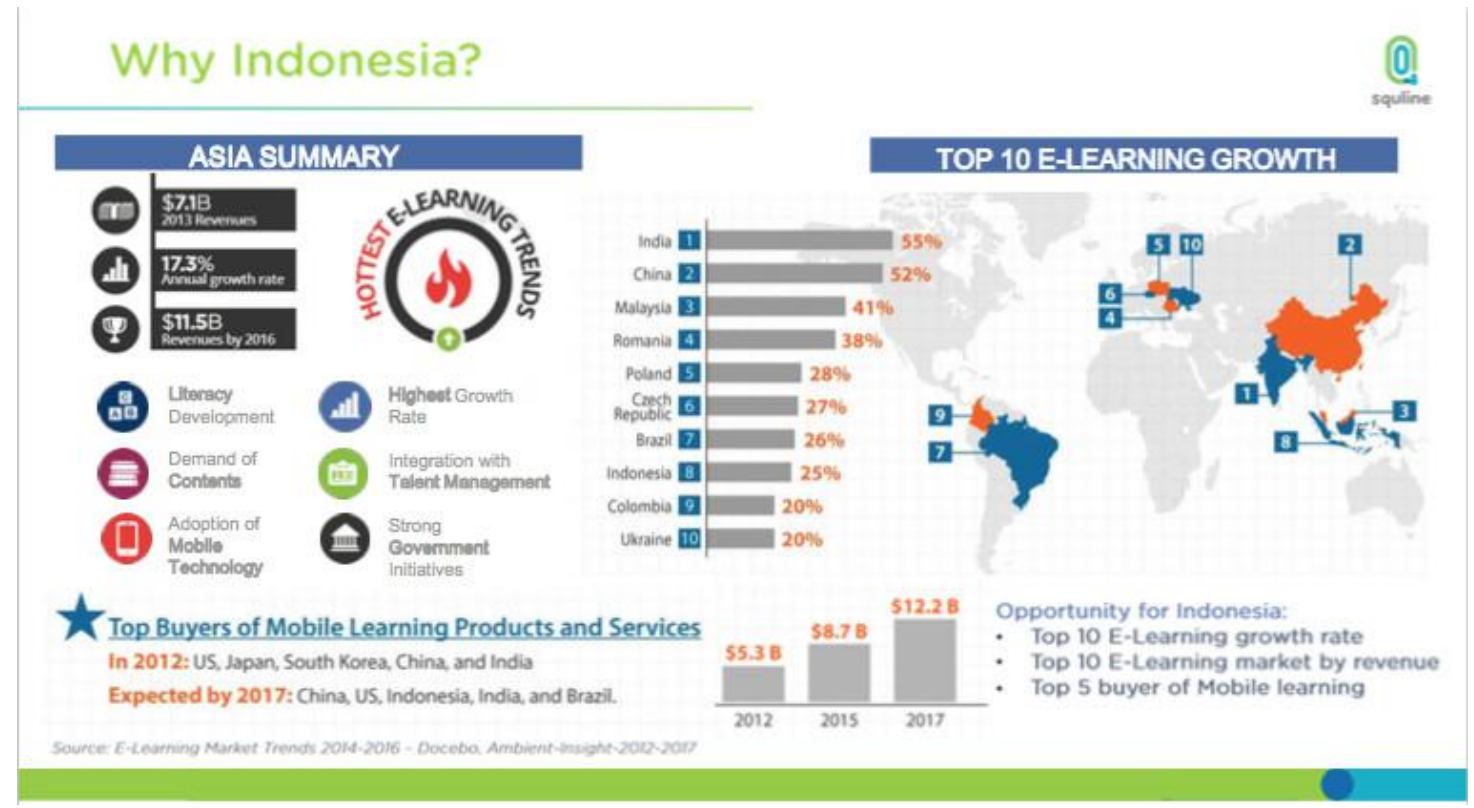

Figure 2 e-Learning market [2]. 
It is undeniable that the use of telemedicine has soared during the COVID-19 pandemic period. It is in line with McKinsey's research results, which noted that $67 \%$ of respondents are interested in using telemedicine services in the future, even after the pandemic has passed.

The trends and potentials offered by this sector, coupled with Indonesia's dense population, of course, have led to an increasing number of local and foreign players entering the telemedicine sector.

In Indonesia, for example, there are several HealthTech services, including Halodoc, Grab Health and others. The e-Economy SEA report for 2020 notes that HealthTech, aka Telemedicine users, quadrupled during the pandemic. The existence of e-health like Halodoc makes health services more accessible.
Based on the description of innovation in Indonesia, every company in Indonesia needs to carry out an innovation strategy to maintain the sustainability of a business by combining all existing processes in a business process by taking into account the uniqueness of its factors, product quality and durability and capability conditions. from competitors. Organizations are believed to be successful if they implement measures that can withstand rapid and dynamic market changes.

Based on the explanation of the innovation provided, it can be illustrated by the business opportunity for a pandemic to support the Less Contact Economy, you can see Figure 3.
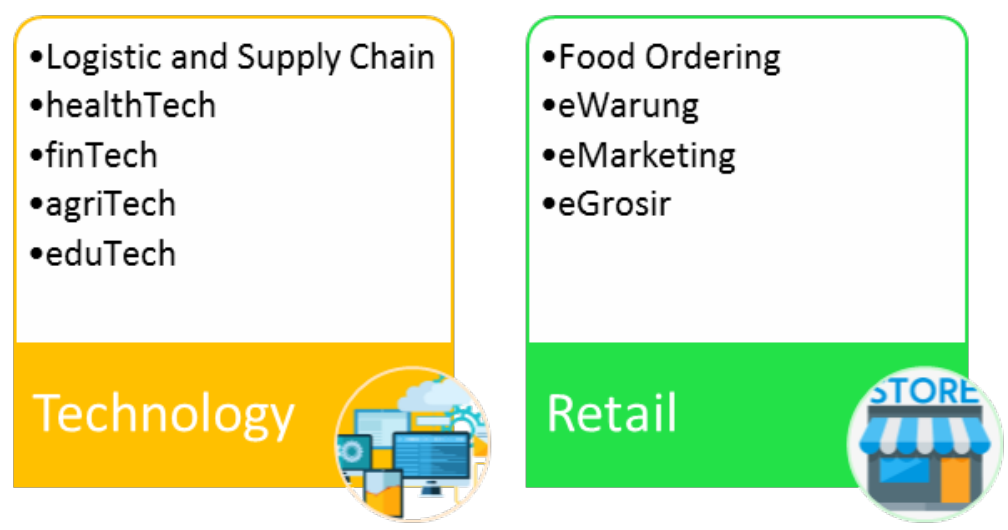

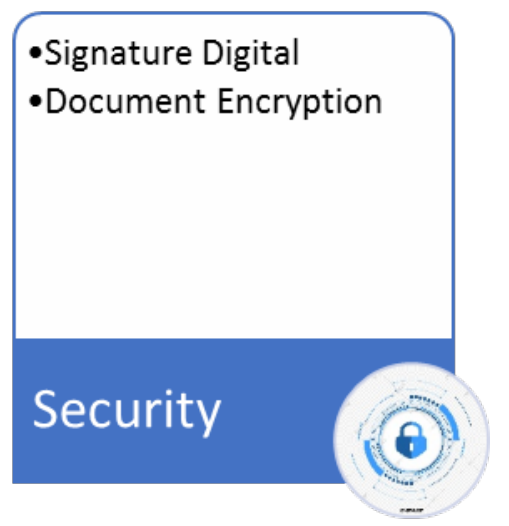

Figure 3 Digital sector

\section{CONCLUSION}

The conclusion is that the COVID-19 pandemic has made life arrangements to adopt new norms to protect people from the increasingly widespread coronavirus. It makes it considered capable of accelerating digitalization widely, from the government system's bureaucracy to the economy and driving consumption that is fulfilled online into mainstream consumption. The use of information technology as a digital sector innovation solution maintains business sustainability in the New Normal era amidst the COVID-19 pandemic. The period has encouraged science and technology to become stronger with collaboration and synergy between researchers from various disciplines to create digital sector innovation known as the New Platform, namely Logistics and Supply Chain, EdTech, FinTech, AgriTech and HealthTech.

A pandemic can be a trigger and encouragement for the bureaucracy in providing services to the community. Advances in technology and public understanding of public services are increasing. The organization is currently increasingly demanding more for the services offered and is continually monitoring, straightening and pushing the government's pace. The government has intensified innovation in the digital less contact economy sector in providing public services. It is essential because digital services are demands that will be able to get closer to society. However, it is necessary to optimize this innovation's application because the essence of digital transformation is not only changing ordinary services online or by building applications. Digital transformation is broader than just turning services online but how to integrate all service areas to produce changes in business processes and create "value" that provides satisfaction to service users.

\section{REFERENCES}

[1] U. Nations, "Putting The Un Framework For Socioeconomic Response To Covid-19 Into Action: Insights," 2020.

[2] liputan6.com, "https://www.liputan6.com/tekno/read/3010481/10 -negara-dengan-pertumbuhan-e-learning-tertinggidi-dunia".

[3] O. W. i. Dataourworldindata.org, "Daily new confirmed cases of COVID-19 - Our World in 
Dataourworldindata.org > The line is blue when the rate of positive tests in a country is low - this means a country performs many tests relative to the size of the outbreak. https://ourworldindata.," 2021.

[4] D. \&. C. D. D. \&. A. S. \&. S. M. Lestari, "International Trade In The Covid-19 Outbreak: Is The Digital Economy Working?," International Journal of Business and Management. VIII. 86-92. 10.20472/BM.2020.8.2.005., 2020.

[5] M. “. D. J. S. P. d. T. W. Covid-19, "https://www.kompas.com/edu/read/2020/04/30/21 3652171/menristek-sektor-digital-jadi-substitusipenting-di-tengah-wabah-covid-19?page=all".

[6] P. K. B. A. T. K. A. P. S. \&. R. R. Paul, "Digital Business towards an Academic and Professional Degree: An International Perspective.," International Journal on Recent Researches in Science, Engineering, 2018.

[7] J. C. J. C.-b. H. H. E. \&. C. J. Frishammar, "Digital strategies for two-sided markets: A case study of shopping malls.," Decision Support Systems. https://doi.org/10.1016/j.dss.2018.02.003, 2018.

[8] A. Kuncoro, "Ekonomi Digital, Inovasi, dan Perilaku Konsumsi.," Seminar Nasional Economic Outlook 2018 Ikatan Sarjana Ekonomi Indonesia Wilayah Jawa Timur 10 Januari 2018. Jawa Timur: Ikatan Sarjana Ekonomi Indonesia, 2018.
[9] E. Tosheva, "COVID-19 Crisis As An Accelerator Of Digital Transformation And Digital Economy.," 2020.

[10] E. Tosheva, "Economic And Social Benefits Of Digital Economy And Digital Transformation In The Republic Of North Macedonia. I," Izmir Journal of Social Sciences, 2 (2), 42-51., 2020.

[11] truckmagz, "https://truckmagz.com/responstrategi-supply-chain-dan-logistik-di-erakenormalan-baru/".

[12] worldbank.org, "https://blogs.worldbank.org/id/eastasiapacific/tek nologi-pendidikan-indonesia-di-masa-covid-19dan-selanjutnya".

[13] M. J. \&. R. Á. Sousa, "Skills for disruptive digital business. Journal of Business Research, (August 2017), 0-1.," https://doi.org/10.1016/j.jbusres.2017.12.051, 2018 https://doi.org/10.1016/j.jbusres.2017.12.051.

[14] C. Indonesia, "https://www.cnbcindonesia.com/news/202101071 32706-4-214173/tiada-pemulihan-ekonomi-tanpamengatasi-pandemi".

[15] S. \&. Mohapatra, "IMPACT OF CORONA VIRUS COVID-19 ON THE GLOBAL ECONOMY.," International Journal of Agricultural and Statistics Sciences. 16. 771-778., 2020. 